\title{
Refusal Strategies Performed by Javanese English as Foreign Language (EFL) learners
}

\author{
Weni Mardi Waluyani, Soepriyatna \\ Faculty of Education, Sampoerna University, Jakarta- Indonesia \\ wenimw@gmail.com
}

\begin{abstract}
Refusal is one of speech acts that people perform. This research specifically identified the most common strategies used in performing refusals and how Javanese EFL learners use the refusal strategies regarding the status of the refuse. The research was conducted in faculty of education Sampoerna University and involved 34 participants. The data were collected using discourse completion tasks (det) and were analyzed using categorization of refusal strategies proposed by Beebe et al. The results show that most of participants utilize indirect strategies especially excuse/reason/explanation as the most common used strategy. In addition the participants are also identified to use direct "head act" and "pre-refusal" strategies in their refusals. The results also indicate that Javanese EFL learners use different refusal strategies depend on the status of the refuse. However, in several cases participants utilize similar strategies to refuse interlocutors' request, offer, invitation and suggestion from different social status.
\end{abstract}

Keywords: refusal, EFL learners, Javanese EFL learners, speech act, refusal strategy

\section{INTRODUCTION}

Refusal is one of speech acts that people perform. Refusal as suggested by Brown and Levinson (1987) is naturally a face- threatening and rapport- threatening speech act. Moreover, as suggested by Sahin (2011) refusal is very culture and context-dependent. Because of that, people from different culture will employ different refusal strategies since every culture has diverse way in protecting speakers' positive face and reducing the threat that occur because of refusal (Brown \& Levinson, 1987).

Javanese as one culture group has its own way to realize refusal according to their culture. According to Endraswara (2010) Javanese group is naturally indirect people, their performance is full of symbols and it causes them to deliver their ideas indirectly to others people. Moreover, Javanese group also has complex politeness system that is showed in their language system. Based on Aziz (2000) Javanese express politeness by manipulating the use of word and they rely on the speech levels available in Javanese language. Javanese language itself is divided into three speech level, krama, used to communicate with higher status people, madya, used to communicate with equal status people and ngaka, used to communicate with lower status people (Sasangka, 2004). Due to that in performing refusal in their first language, Javanese will tend to use indirect strategy, and to use different speech level, depending on the status of the refusee.
The problem arises when Javanese, as EFL (English as Foreign Language) learners have to perform refusal in target language which is English. It is because based on Lubis (1981) the indirectness in performing a refusal or an acceptance make some people especially non-Indonesian people feel it very difficult and frustrating. In addition Aziz (2000) discovers that the indirectness of performing refusal and reluctance to refuse lead the interlocutors to stereotype speakers as impolite and hypercritical.

Therefore this present research attempts to investigate how Javanese EFL learners will realize refusal in English in various situations and examine if Javanese indirect nature will be reflected on the refusal they perform in English. Hence this present research is designed to answer the following research questions: 1) what are the most common strategies used by Javanese EFL learners in performing refusal? 2) how do Javanese EFL learmers use refusal strategies regarding the status of the refusee?

\section{METHODS}

This present research was conducted using qualitative research. The population of this research was Javanese students of Sampoerna University, Faculty of Education (FoE), from cohort 2010, 2011 and 2012. To determine the number of the population researcher conducted a survey. The researcher selected the participants from the population by using purposive sampling. There were two filters for selecting the participants. First was cultural background filter in which participants were selected according to their cultural background and only Javanese students were selected. Second was language proficiency filter to find Javanese students whose English proficiency was sufficient. After filtering the population, the total number of the research participant was 34 people. The instrument used in this research was adopted from Beebe' Discourse Completion Task (DCT) which was made in 1990.

\section{FINDINGS}

The research findings cover one major finding namely refusal performed by Javanese EFL learners regarding the social status. In addition the collected data were analysed by 1) dividing the refusal into refusal sequences (pre-refusal, head act and post refusal), 2) breaking down the refusal into semantic formula and 3) categorizing the semantic formula into two refusal strategies and adjunct to refusal proposed by Beebe, et al (1990). 
Refusal performed by Javanese EFL learners to higher status refuse

The research findings show that the mostly used refusal sequence is using pre-refusal and head act. Regarding the most commonly strategies used, the refusals performed by participants mainly fall into three refusal strategies. Those are 1) excuse/reason/explanation, 2) statement of regret and 3) statement of negative willingness/ability.

\section{Refusal performed by Javanese EFL learners to equal status refuse}

The research findings suggest that most of participants do not use pre-refusal and post- refusal strategy; instead they directly perform head-acts. Concerning the most commonly used refusals strategies, the refusals performed by participants are mainly distributed in four refusal strategies namely: 1) excuse/reason/explanation, 2) statement of regret, 3) no statement and 4) statement of negative willingness/ability.

Refusal performed by Javanese EFL learners to lower status refuse

The research findings indicate that most of participants perform refusal without pre - refusal and postrefusal and directly perform head- act. Concerning the most common refusal strategies used, the refusals performed by participants are mainly distributed in four refusal strategies namely 1) excuse/reason/explanation, 2) let interlocutor off the hook, 3) statement of regret and 4) statement of negative willingness/ability. The research findings suggest that in performing refusal to lower status refusee participants employ less direct strategy compare to performing refusal to higher and equal status refusee.

\section{DISCUSSION}

Most of participants use pre-refusal strategy to refuse higher status refusee might happen because Javanese people characteristic to adhere towards status difference. Javanese according to Hofstede (1986) is a cultural group with large power distance. This suggests that Javanese people with lower status in Javanese community consciously and willingly accept the inequality in authority and consider it as normal thing. In addition in his another study, Hofstede (1991) discovers that in Javanese community, people with lower status think it is normal for them to speak with high speech level to people with higher status to maintain harmony and togetherness, hence direct confrontation to another people is considered as rude and undesirable. Thus the usage of prerefusal strategy in refusing higher status refusee might be realization of participants attempt to communicate with high speech level and maintain harmony and togetherness.

As for the refusal strategy performed by participants to higher status refusee, the research findings indicate that there are three most common used refusal strategies. Those are 1) excuse/reason/explanation, 2) statement of regret and 3) statement of negative willingness/ability. In addition most of participants employ adjunct to refusal: gratitude/appreciation as pre- refusal strategy. Aside from that, the research findings suggest that participants have tendency to combine the three most commonly used refusal strategies (excuse/reason/explanation, statement of regret, and statement of negative willingness/ability) in their performed refusals.

Although participants use direct strategy to perform refusal, the direct refusals often are accompanied by indirect strategies such as excuse/reason/ explanation and statement of regret. This might happen because Javanese people have feeling of "ajrih". According to Koentjaranigrat (1985) "ajrih" is a fear felt by Javanese people because they cannot predict what other people capable of and what other people will do to them. Javanese people have feeling of "ajrih" toward higher status people in Javanese community. Hence participants' refusals which combine between direct and indirect refusal strategies might be cause by their "ajrih" feeling and attempt not to offend the interlocutor (higher status refuse).

Besides, the research findings suggest that most of participants use statement of regret expression "I am sorry..." and "I am so sorry..." in refusing the interlocutors. In addition, several participants use expression "I apologize...", "I am afraid..." and "Unfortunately..." in their refusals. The research finding in this present research is in line with Hofstede study (1991). Hofstede (1991) discovers that in order to mitigate the effect of the refusal, Javanese EFL learners often use the excessive terms of address and expression of apology such as forgive, regret and apologize because of the assumption that common expression as "sorry" is not strong enough to express their feelings. The usage of excessive term of address and expression of apology also might cause by participants" "ajrih" feeling.

In refusing to equal status refusee, most of participants do not use pre-refusal and post- refusal strategy instead they directly perform head-acts. Aside from that the lengths of the collected refusals in refusing equal status refusee are varied. Several of refusals are considerably short in contrary several of the refusals are substantially lengthy.

The considerably short refusals might be the result of the status of the interlocutor (equal status refusee). According to Sahin (2011) in performing refusals to equal status refusee, speakers might have tendency to use different refusal strategy which depend on the closeness level of their relationship such as friend, best friend or lover. In addition Spencer-Oatey (2008) argues that speakers tend to use different refusal strategy because the relationship between equal status refusee and speaker is free from the impact of power because there is no person whose possess superiority..

In regards the refusal strategies used by participants, the research findings indicate that the mostly used refusal strategies are 1) excuse/reason/explanation, 2) statement of regret, 3) no statement and 4) statement of negative willingness/ability. Besides, the research findings suggest that in using direct refusal strategy participants often combine it with indirect strategy such as excuse/reason/explanation, statement of regret and others strategies. Yet, the research 
findings also discover that several participants combine indirect strategy with other indirect strategy.

These findings support Aziz's finding (2000) which states that Javanese people are actually quite direct in performing refusals because they often use word "no" , "tidak", "nggak" and "ndak". The findings which reveal that participants often combine the direct and indirect strategy also support Aziz (2000) who concludes that Javanese people often mitigate direct/explicit refusals with the usage of indirect strategies as politeness strategy.

Besides, as has been discussed in the previous sub section, combining between direct and indirect strategy might happen because Javanese people's characteristic to conceal one's feeling toward other. It is because concealing one's feeling which conflict with other people' desire, wishes and intention are often labeled as inappropriate in Javanese community (Wierzbicka, 1991). Thus Javanese EFL learners might use indirect refusal strategies to mitigate their action (revealing their true feeling and opinion) which can be taken as rude, impolite and inappropriate by their community.

As for combining indirect and others indirect strategies, Javanese EFL learners might combine the strategy because of their characteristics. Those characteristics are indirectness and concealing one's feeling towards others. In order to maintain relationship with others, Javanese people will do almost everything including being indirect and concealing their feeling toward others (Nadar, 2007). Based on Wierzbicka (1991) in Javanese community there is situation called as "not saying what one feels" and the need "to protect one's own equanimity and peace of mind which could be threatened by an overt expression of feeling". Meanwhile for the indirectness according to Nadar (2007) Javanese people find it difficult to say no or to express refusals especially to the interlocutors who are higher or equal status people because of Javanese culture which value togetherness, solidarity and friendship.

In addition the finding which states participants combine indirect and others indirect strategy is in line with Aziz's research findings (2000) which discover that Javanese people use verbosity not only in explicit or direct refusal but it is also used in indirect refusal. Aziz (2000) concludes that combining indirect and others indirect strategies cannot be merely perceived as politeness strategy. It is because verbosity in indirect refusals can be perceived differently by different interlocutors. Several interlocutors might consider it as politeness strategies while others might find it annoying because the verbosity does not give the clarity of either they are being refuse or accept.

Third is the refusal performed by participants to lower status refusee. In performing refusals to lower status refusee, the mostly used refusal sequence is directly performing head act. Yet, the research findings reveal that the difference between the first mostly used refusal sequence (head act) and the second mostly used refusal sequence (prerefusal) is only one refusal. In addition, the research findings show that most of refusals perform to lower status refusee are considerably lengthy.
The aforementioned research findings is a contra to Errington's finding (1988) which states that although Javanese people have difficulties in performing refusals to higher and equal status interlocutor, yet it is easier for them whose status is higher than the interlocutor to perform refusals. The research findings also strengthen the notion that Javanese characteristics of being indirect and hiding one's feeling towards others influence their language production especially in other language than their first language Nadar (1999).

Concerning the refusal strategies used by participants in performing refusal to lower status refusee, the research findings discover that the refusals strategies used are mainly distributed in four refusal strategies namely 1) excuse/reason/explanation, 2) let interlocutor off the hook, 3) statement of regret and 4) negative willingness/ability. Besides, the research findings suggest that in performing refusal to lower status refusee participants employ less direct strategy compare to performing refusal to higher and equal status refusee.

Although Errington (1988) argues that for Javanese whose status higher compare to the interlocutors perform refusals will be easier. The present research findings show that easiness to perform refusal to lower status refusee does not correlate to directness of the refusal. This situation might occur because of Javanese people characteristics, which are indirectness and avoiding responsibility and attention.

Errington (1988) argues those aforementioned characteristics are related to each other. It is because by being indirect Javanese people are able to avoid becoming the object of overly direct reference. In daily life Errington (1988) finds that the characteristic of indirectness and avoiding responsibility and attention are reflected in Javanese people's language production. A lot of Javanese people prefer to use pronoun "We" instead of " $I$ ", since by using "We" the speaker does not bear the responsibility alone of what he says but the hearer also share the same responsibility. In connection of speech acts production particularly refusals performed by Javanese people, Kana (1982) suggest that one of ways to avoid responsibility and attention is by giving excessive apologizes and detailed reasons or justifications to the interlocutor. All of those aforementioned speech acts (apologize, reason and explanation) can be realized by using indirect strategies not direct strategies.

Several participants are identified to use refusal strategy statement of philosophy in refusing to lower status refusee's suggestion. The usage of statement of philosophy might be realization of participants' indirectness and preference to hide one's true feeling toward others. It is because statement of philosophy often hard to decipher by the interlocutors/refusee. As for the particular usage of statement of philosophy to lower status refusee, this might occur as the derivation of Javanese traditional old system in Kingdoms era. According to Wierzbicka (1991) Javanese people tendency to be indirect and hide their feeling might be derived from the system of traditional Javanese king where his subjects need to interpret the king's saying. Hence it is important for interlocutors to figure out the real feeling, wish or intention of 
the speakers through other elements aside from words such as symbols and gestures. In this case, participants are put as people whose status is higher or act as the king. In contrary the refusee is positioned as lower status people or subject. Thus participants might adapt Javanese kings' way to communicate with lower status interlocutor through using statement of philosophy.

Last, the research findings suggest that most of participants use strategy let interlocutor off the hook in refusing lower status's offer. In contrary participants do not refuse using let interlocutor off the hook to higher and equal status refusee' $s$ offer. It is because most of participants use excuse/reason/explanation to refuse higher and equal status refusee's offer.

Participants might use strategy let interlocutor off the hook because of the existence of Javanese semantics primitives suggested by Wierzbicka (1991) which are "I don't want to feel something bad" and "I don't want someone to feel bad as well." By letting the interlocutor, in this case lower status refusee off the hook, participants can employ the principle "I don't wants someone to feel bad." Moreover, it also might cause by Javanese people's preference to togetherness. By letting the interlocutor of the hook Javanese people can maintain what are important to them, which are according to Koentjaranigrat (1985) are staying together and maintaining the harmony relationship with every member of community or group.

\section{CONCLUSION}

Regarding the first research question about the most commonly used strategies by Javanese EFL learners, it can be concluded that most of participants perform refusals in two refusal sequence namely: 1) head act and 2) using pre-refusal strategy and the most common strategy used by participants is excuse/reason/explanation. As for the second research question which concerns about how Javanese EFL learners perform refusals regarding the social status, the present research concludes that participants employ different strategies in refusing people with different status yet in several situations the strategies used are similar. In addition participants' ways of realizing refusals to refusee from different status are often influenced by their first language and culture.

\section{REFERENCES}

Aziz, E, A. (2000). Refusing in Indonesian: Strategies and politeness implication. (Doctoral dissertation). Monash University: Australia.

Beebe, L. M., Takahashi, T. and Uliss-Weltz, R. (1990). Pragmatic transfer in ESL refusals. In: Anderson, E., Krashen, S and Scarcella, R. (Eds.). Developing communicative competence in a second language, Newbury House, New York, 55-73.

Brown, P. \& Levinson, S. C. (1987). Politeness: Some universals in language usage. Cambridge: Cambridge University Press.
Endraswara, S. (2010). Etika hidup orang Jawa: pedoman beretika dalam menjalani kehidupan sehari-hari. Yogyakarta: Narasi.

Errington, J, J. (1988). Structure and style in Javanese: A semiotic view of linguitics etiquette. Philadelphia: University of Pennsylvania Press.

Hofstede, G. (1986). Cultural differences in teaching and learning. International journal of intercultural relations, 10, 301- 320.

Hofstede, G. (1991). Cultures and organizations: software of the mind. London:Mc-Graw Hill Book Company.

Kana, M. (1982). Saying no in English: A sociolinguistics lesson on refusals. RELC journal, 13 (2), 22-50.

Koentjaranigrat. (1985). Javanese culture. Oxford: Oxford University Press.

Lubis, M. (1981). Manusia Indonesia (sebuah pertanggungjawaban). Jakarta: Yayasan Idayu.

Nadar , FX. (1999). Transfers of Javanese culture in the production of English utterances and its possible impact on inter-cultural interaction. Humaniora, 11, 1- 6.

Nadar, FX. (2007). The prominent characteristics of Javanese culture and their reflections on language use. Humaniora, 19 (2) , 168- 174.

Sahin, S. (2011). American English, Turkish and interlanguage refusals: A cross- cultural communication and interlanguage pragmatics study. (A master's thesis). The Graduate School of Social Science of Middle East Technical University, Turkey.

Sasangka, S. (2004). Unggah ungguh bahasa Jawa. Jakarta: Yayasan Paralingua.

Spencer-Oatey, H. (2008). Face, (Im)Politeness and Rapport. In Helen Spencer-Oatey (Ed.), Culturally speaking: Culture, communication and politeness theory (pp. 1146). London \& New York: Continuum.

Wierzbicka, A. (1991). Cross cultural pragmatics: The semantics of human interaction. Berlin: Mouton de Gruyter. 